\title{
Nesen - mer enn til å snyte seg i!
}

Nesen har mange funksjoner: Luktesansen ligger der, og i nesen fuktes og tempereres luften som passerer. Luktesansområdet er lite og ligger dypt i nesen. Mesteparten av neseslimhinnen er respiratorisk epitel som er meget godt sirkulert av «tynnveggede» kapillarer med fenestrae vendt mot overflaten. Det ligger til rette for at medikamenter kan tas svært raskt opp i blodbanen og gi systemisk virkning (1).

Nesespray administreres på en svært enkel måte og muliggjør dessuten raskt medikamentopptak (2). Det gjør at den er interessant både for pasienter (ikke minst barn, som slipper unødig stikking), for prehospital helsetjeneste, og også for legfolk i visse situasjoner.

Smertebehandling med nesespray er allerede et etablert tilbud. Triptaner til migrenebehandling er et godt og kjent eksempel på at nesespray forenkler administrasjonen, ikke minst når kvalme og oppkast gjør oral tilførsel vanskelig.

Publikasjoner som omhandlet bruk av nasale opioider kom omkring 1990. Man brukte intravenøse formuleringer som nesespray til pasienter med akutt, postoperativ smerte. I en oversiktsartikkel fra 2002 ble det konkludert med at nasalt fentanyl var lovende pga. god biotilgjengelighet og rask virkning (1). Imidlertid er ikke utvikling av preparater for nasal administrasjon noe for amatører. Sprayvolumet bør være mindre enn $200 \mu \mathrm{l}$. Det betyr at intravenøse preparater ikke er egnet fordi de er for lite konsentrert. Den mukociliære transporten mot pharynx begrenser også tid for opptak til ca. 15 minutter.

På 1990-tallet ble det utviklet en nesespray med det potente opioidet fentanyl, samtidig som man innen palliativ medisin satte søkelyset på at en del pasienter med kreftrelatert smerte var plaget med såkalt gjennombruddssmerte. Dette er som regel en vilkårlig, hurtig innsettende, sterk smerte med varighet på mindre enn 30 minutter. Standardbehandling var oralt, «hurtigvirkende» opioid. Nasalt fentanyl er nå på markedet for denne indikasjonen.

Det er grunn til å tro at nasale opioider også har et potensial for akuttmedisinisk bruk. Invasive prosedyrer som intravenøs eller intramuskulær administrasjon kan både være vanskelige å utføre og være smertefulle for barn. Hos barn med frakturer og andre skader, både ute i felten og ved innkomst i akuttmottak, kan man oppnå god smertelindring med nasale opioider. Preliminære studier har ikke overraskende vist at barn med fraktur (og deres foreldre) ga uttrykk for mye større tilfredshet med nesespray enn med intramuskulært opioid (3).

Et annet område innen akuttmedisinen hvor nasal administrasjon kan være interessant, er bruk av bensodiazepiner ved epileptiske anfall. Man har behov for raskt innsettende virkning, og intravenøs tilgang kan være vanskelig. Tidligere var pasientene ofte utstyrt med suppositorier slik at arbeidskamerater eller familie kunne hjelpe til under anfall. Men å sette suppositorier på en arbeidskamerat under krampeanfall var ingen delikat affære. I dag er bukkalt midazolam tilgjenglig (4). Men nesespray ville vært enklere å dosere, i alle fall til voksne $(5,6)$ og virkningen ved nasal administrasjon antakelig raskere og mer forutsigbar.

Nasal administrasjon av opioidantagonisten nalokson som brukes ved heroinoverdoser har et betydelig akuttmedisinsk potensial. Nalokson nasalt kan også være viktig for utrykningspersonellet; det er ikke alltid like lett å finne venetilgang ved overdosetilfeller (7). Nasal spray kan også redusere mulighetene for nålestikksskade eller søl med mulig infisert blod. Det største potensialet for livreddende intervensjon kan imidlertid være å utstyre brukermiljøet og foreldre med nasalt nalokson. Nasalt nalokson til brukermiljøene er faktisk på den politiske agendaen i Norge. Brukere i allianse med politikere ønsker rask innføring for å bekjempe overdosedødsfall. Det er studier som gir støtte for at brukermiljøet er i stand til å yte slik førstehjelp (8). Men resultatene kunne vært enda bedre dersom man hadde brukt en «profesjonell» nasal naloksonspray med kjent kinetikk, istedenfor å bruke en komplisert forstøver (atomizer) med relativt store volumer av en intravenøs løsning med ukjent farmakokinetikk. Man må ha grunnleggende farmakokinetisk kunnskap for å kunne dosere rasjonelt, og det bør utføres et minimum av kontrollerte studier innen prehospitalmedisinen før man går til kontrollert utprøving av utplassering i brukermiljøet. Men det finnes også andre bekymringer. Noen frykter at man vil ta større sjanser med motgift innen rekkevidde, andre at man forsinker ambulansetilkalling. Det er også frykt for at torpedoer tvinger nasalt nalokson på dårlige betalere for å utløse en brutal abstinens.

Nasal administrasjon ved akutte smertesituasjoner, epilepsi og overdoser kan være til stor nytte for både barn og voksne, og ikke minst for pårørende. Nyttige nasale medikamentformuleringer for akuttmedisinsk bruk kommer ikke av seg selv, det kommersielle potensialet er ikke stort på disse indikasjonene. Men har ikke samfunnet et ansvar for at det kan gis gode akuttmedisinske behandlingstilbud uavhengig av den farmasøytiske industrien? Og bør ikke samfunnet stille krav til at nye behandlingstilbud baseres på et solid kunnskapsgrunnlag?

\section{Ola Dale}

ola.dale.@ntnu.no

Ola Dale (f. 1948) er anestesiolog og klinisk farmakolog. Han er professor ved Det medisinske fakultet, Norges teknisk-naturvitenskapelige universitet og St. Olavs hospital og medlem av redaksjonskomiteen i Tidsskriftet.

Oppgitte interessekonflikter: Forfatteren har mottatt forelesningshonorar fra Nycomed.

\section{Litteratur}

1. Dale 0 , Hjortkjaer R, Kharasch ED. Nasal administration of opioids for pain management in adults. Acta Anaesthesiol Scand 2002; 46: 759-70.

2. Moksnes K, Fredheim OM, Klepstad P et al. Early pharmacokinetics of nasal fentanyl: is there a significant arterio-venous difference? Eur J Clin Pharmacol 2008; 64: 497-502.

3. Kendall JM, Reeves BC, Latter VS. Multicentre randomised controlled trial of nasal diamorphine for analgesia in children and teenagers with clinical fractures. BMJ 2001; 322: $261-5$

4. Nakken KO, Rytter EM, Brockmeier F. Benzodiazepiner i behandlingen av epilepsi. Tidsskr Nor Legeforen 2010; 130: 842-4.

5. Lindhardt K, Gizurarson S, Stefansson SB et al. Electroencephalographic effects and serum concentrations after intranasal and intravenous administration of diazepam to healthy volunteers. Br J Clin Pharmacol 2001; 52: 521-7.

6. Dale 0 , Nilsen T, Loftsson T et al. Intranasal midazolam: a comparison of two delivery devices in human volunteers. J Pharm Pharmacol 2006; 58: 1311-8.

7. Merlin MA, Saybolt M, Kapitanyan R et al. Intranasal naloxone delivery is an alternative to intravenous naloxone for opioid overdoses. Am J Emerg Med 2010; 28: $296-303$.

8. Doe-Simkins M, Walley AY, Epstein A et al. Saved by the nose: bystanderadministered intranasal naloxone hydrochloride for opioid overdose. Am J Public Health 2009; 99: 788-91. 